very severe cracking developed in concrete specimens after a single winter's oxposure on the exposure site at Thorntonhall, noar Glasgow. It was later found that the dolorite rock itself exhibited large dimensional changes in water content". Volume changes duo to chemical reaction were investigated but not substantiated. Since dimensional changes on wetting and drying of the rock itself occurred, a study was mado of the expansion and contraction caused by moisture in various Scottish dolerites and concrotes mado from them. The experiments were oxtended to other rock-types as well as natural sands and gravels used as aggregates for concrete. The arguments in this paper are convineing and establish that many natural crushed rock and gravel aggregates undergo changes of volume as they take up water, thus influencing both the shrinkage and the durability of the concrete in which they are incorporated.
H. B. Milner

\title{
DEMOGRAPHY OF MAURITIUS
}

T HREE hundred and fifty years ago the island of Mauritius was uninhabited by man. The only creatures there were some indigenous reptiles and birds, and a few domestic animals left by passing sailors. To-day, the dodo is extinct, but within the island's narrow confines lives one of the most rapidly growing human populations in the world.

Mauritius is a hurricane-battered island in the Indian Ocean. It is about 500 milos east of the island of Madagascar, more than twico that distance from the south-eastern coast of Africa, and 200 miles north of the Tropic of Capricorn. In a land area of $720 \mathrm{sq}$. miles, there are 990 Mauritians for every square milo, an immense burdon for the island's meagro natural rosources and limited facilities. Until 1946 , the rate of natural increase was low. Immigration accounted for almost half the total growth. In 1946 thore were 428,000 people on the island. Recently, a dramatic shift in the survival pattern upsot the two-centuriesold balance between births and deaths which had held tho population in check. In just five years, the deathrate dropped from 36 to 14 and the birth-rate roso from 38 to 50 per thousand of the population per year.

It is estimated that, in 1961 , there wore 656,000 people on the island, an increase of more than 50 per cent in only 15 years. During the period, natural increase averaged 2.9 por cent a year, one of the highest rates in the world. Immigration had not been an important feature in population growth. By 1961 the Mauritian death-rate was 10 , lower than that of the highly urban-industrial United Kingdom. The
Mauritial birth-rate had recedod to 40 , a rate typical of those found in less-developed countries. Should the phenomenally rapid multiplication of people continue, Mauritius would have a population of more than two million in the year 2,000-a three-fold increase in only 39 years.

One of tho most serious consequences of this over-rapid growth is a population with a bottomhoavy age structuro which adds to Mauritius's economic difficulties. To-day, 44 per cent of the population is under 15 and another 3 per cent is 65 years or older. If the rate of population growth is maintained, the increase in the economically depend. ent age-groups could strangle the economy. In lass than 25 years, the numbor of children undor 15 alone would be larger than the entire population in 1960.

This island is one of the few less-developed countries with a tradition of reliable vital statistics, introduced by the British. Thus, Mauritius serves as an almost perfect small-scale example of how toorapid population growth can depress living-lovels when the resource base is meagre and limited.

There seems to be but one ray of hope in Mauritius. Although the birth-rate is still alarmingly high, it has declined from its record peak of 50 in 1950 to 40 in 1961. The way in which the rising population of Mauritius may be controlled has been described by Robert C. Cook, editor of Population Bulletin*.

* Population Reference Bureau. Population Bulletin, 18 No. 5 ; August 1962: The Story of Mauritius-From the Dodo to the Stork: 1962.) 50 cents.

\section{LACK OF ACTIVATION OF PHOSPHORYLASE BY ADRENALINE DURING ITS PHYSIOLOGICAL EFFECT ON INTESTINAL SMOOTH MUSCLE}

\author{
By Prof. E. BUEDING
}

Department of Pathobiology, Johns Hopkins University, Baltimore, Maryland

\author{
Dr. E, BÜLBRING, F.R.S., and Dr. H. KURIYAMA
}

Department of Pharmacology, University of Oxford

AND

Dr. G. GERCKEN

Physiologisches Institut, Universität Köln

\begin{abstract}
A
$\mathrm{N}$ activation of phosphorylase by adrenaline has been observed in liver, skeletal muscle and heart muscle in vitro and in vivo ${ }^{1}$. When conventional experimental procedures were used, similar results were obtained from isolated intestinal smooth muscle preparations from the taenia coli of the guinea piga ${ }^{2}$. An improved technique was used for the oxporiments to be describod in this communication, and the results show that an activation of phosphoryl-
\end{abstract}

ase does not occur in the tissuo while the physiological effect takes place, and that earlier results ${ }^{2,3}$ must be ascribed to a conversion of phosphorylaso $b$ to phosphorylase $a$ during the period which elapsed between the removal of the tissue from the adrenaline-containing medium and the assay of enzymatic activity. As these observations are limited to a single type of smooth muscle, they do not rule out the possibility that activation of phosphorylase has a relationship 